\title{
The impact of social media marketing on brand equity - A perspective of the telecommunication industry in Ghana
}

\author{
George Kofi Amoako \\ Central University Accra, Ghana \\ Bernard K. Okpattah \\ Lancaster University Ghana Campus, Ghana \\ Emmanuel Arthur \\ Central University Accra, Ghana
}

\author{
Keywords \\ Social Media Marketing, Brand Equity, Telecommunication Industry, Ghana
}

\begin{abstract}
Purpose - As the digital version of word-of-mouth, social media represents the materialization, storage, and retrieval of word-of-mouth content online. The study examined the social media marketing activities of Vodafone and MTN Ghana's Facebook pages and the objectives set for this purpose were to determine whether social media marketing activities enhance brand equity, identify the kind of social media marketing activities that enhance brand equity and investigate the effects of social media marketing on brand equity.

Design/Methodology - The study used 203 valid responses out of 300 questionnaires that were distributed. The study used the quantitative research method; and the quantitative data was analysed using the PLS approach of the Structural Equation Model (SEM).

Results/Findings - Results showed that social media marketing contributed more to the brand association, loyalty and perceived quality dimensions on brand equity.

Practical Implications - Individually, the Facebook interaction activities assessed in the study proved relevant in attaining brand equity at MTN and Vodafone Ghana. Whilst picture interaction with consumers generated significant improvements in all dimensions of brand equity; liking a brand's page is only a significant contributor to brand awareness and association with video interaction also contributing significantly only to brand loyalty and perceived quality. This goes to show that the social media marketing activities should not be pursued in isolation, but should be done so together to obtain optimum benefits

Originality - The presence of social media is exploding in Ghana however there is little to show for whether this presence actually generates any form of return on investment or brand equity. The study is original since it revealed that there is a positive and significant relationship between social media marketing activities and brand equity. The study recommends that marketing or brand managers should concentrate their efforts largely on brand loyalty, which has high importance in the construct of brand equity, and will further contribute positively to the organization's brand equity.
\end{abstract}

Corresponding author: George K Amoako

Email addresses for the corresponding author: gamoako@central.edu.gh

First submission received: $2^{\text {nd }}$ March 2018

Revised submission received: $30^{\text {th }}$ June 2018

Accepted: $25^{\text {th }}$ September 2018

\subsection{Introduction}

The advent of social media has created a new digital space and grid of connections that enable brands and consumers to communicate without restrictions in time, place and medium. Generally, social media is a collection of online social platforms that enable users to share information, ideas and interests and to interact via the internet or mobile systems such as smartphones (Ates, 2013; Neti, 2011; Richter \& Koch, 2007). The online social platforms include chat rooms, discussion forums, location services, social networking, social guides, social bookmarking, social status networks, weblogs, blogs, podcasts, video casts and wikis. Keller (2009) notes that social media facilitates more rapid and effective information dissemination to consumers than traditional media such as TV, radio and print advertisements. This is 
because brand communication is created and disseminated through user-generated social media communication by consumers themselves. More importantly, their reviews or comments about brands quickly generate a buzz and have the tendency to affect consumer buying behaviour (Wolny \& Mueller, 2013; Genseler et al., 2013). For instance, Facebook fan pages have become a credible information source for consumer reviews of brands and their products and services (Obal, Burch, \& Kunz, 2011). In fact, about $70 \%$ of internet users trust the evaluations of consumers on social media platforms (Nielsen, 2009) and these online reviews have been shown to impact firm performance (Genseler et al., 2013).

Brand equity is an important concept for understanding the objectives, mechanisms and the net impact of marketing efforts (Reynold \& Philips, 2005). Aaker (1991) defines brand equity as a set of brand assets and liabilities linked to a brand, its name and symbol that add to or subtract from the value provided by a product or service to a firm and/or to that firm's customers. According to Yoo and Donthu (2001), brand equity marks the difference in consumer choice between the focal branded product and an unbranded product given the same level of product features. Hence, brand equity generates value for consumers and helps brands create defensible competitive positions that cannot be easily transferred to other brands (Pitta \& Kastsanis, 1995). Brands have resorted to several strategies including advertising, sales force, public relations, slogans and symbols in the attempt to develop brand equity (Aaker, 1991). Yazdanparast et al. (2015) opine that social media-based marketing activities tend to be an effective marketing strategy to build brand equity in this digital era. Consequently, brands have incorporated social media marketing into their marketing strategies to build lasting relationships and connections with consumers (Erdogmus \& Cicek, 2012). Social media marketing is the process of promoting products and services via online social channels and platforms (Weinberg, 2009) through content generation, communication, outreach and referrals to increase web traffic, awareness and popularity of brands (Kim $\&$ Ko, 2012).

As noted earlier, social media is fast becoming the preferred source of information about products, services and brands for consumers. Consequently, Ha (2015) reports that there are over 40 million active small business pages on Facebook. Moreover, social media forms a key component of the marketing and brand management strategies of global companies with strong brand identities, such as Coca-Cola, Starbucks, JP Morgan Chase etc. (Morrissey, 2007). Developing economies have witnessed phenomenal growth in social media presence, and Issaka (2015) reports that the most visited website in Ghana is Facebook, ahead of local news sites and even the search engine giant, Google. It is not surprising, therefore, that telecommunication network operators in Ghana have created Facebook pages to provide consumers with up-to-date information on their products, services, promotions and values with the intent to promote positive word-of-mouth as consumers are able to share their experiences with the brand in their immediate online social communities. But does the strong social media presence and associated social media marketing activities of the network operators generate any form of return on investment or brand equity?

It is important, therefore, to examine the nature of consumer engagement within interactive online social settings on a brand's ability to generate equity (Yazdanparast et al., 2015) in Ghana's telecommunications sector. Facebook fan pages have become a credible information source for customer reviews of brands and their products (Obal et al., 2011). Hence, this paper investigates the social media marketing effect on brand equity of network operators using Facebook to answer the following questions: (i) does social media marketing create brand equity in Ghana's telecommunications sector? and (ii) which social media marketing activities create brand equity in Ghana's telecommunication sector?

\subsection{Literature Review}

\subsection{Social Media and Marketing}

In recent years, the rise of a new generation of information and communication technologies, which are collectively referred to as Web 2.0 or social media, has been phenomenal. They are propelling a new wave of fostering innovation and creating intellectual capital creation (Faraj, Jarvenpaa \& Majchrzak, 2011). Kaplan and Haenlein (2010) define Web 2.0 as a new way in which end users use the World Wide Web; a place where content is continuously altered by all operators in a sharing and collaborative way. Web 2.0 has evolved from simple information retrieval to include interactivity, interoperability, and collaboration (Campbell et al., 2011). Social media thus comprises of Internet based applications that build 
on the ideological and technological foundations of Web 2.0 and allows the creation and exchange of user generated content (Kaplan \& Haenlein, 2010). To meet the requirements as a social network platform, a site must contain user profiles, permit users to connect with others and post comments on each other's pages, and join virtual groups based on common interests (Gross \& Acquisti, 2005; Ellison, Steinfield \& Lampe, 2007; Lenhart \& Madden, 2007; Winder, 2007; Boyd \& Ellison, 2007 as cited in Cox, 2010).

The emergence of social media platforms facilitates consumer-to-consumer communication and accelerates communication especially between unknown consumers (Duan, Gu \& Whinston, 2008). In a study conducted by Nielsen (2009), it was noted that $70 \%$ of internet users trust the evaluations of consumers on social media platforms. As a result, marketers can expect that brand communication will cease to be generated solely by the company, but increasingly by the consumers themselves through usergenerated social media communication. As a result, social media enables word-of-mouth communication from consumer to consumer in the online environment. Considering that consumers are increasingly reliant on their social networks when making purchase decisions (Hinz, Skiera, Barrot, \& Becker 2011), social media word-of-mouth among consumers is crucial for brands as it is faster and more far-reaching than traditional word-of-mouth.

Social media is increasingly becoming both a communication and marketing tool worldwide. Many companies have thus developed their marketing strategies and brand-management around social media incorporated (Morrissey, 2007). This is because social media facilitates listening, information gathering, and a two-way engagement between brand managers and consumers; for instance, there are over 40 million active small business pages on Facebook (Ha, 2015). In comparison with traditional media and direct marketing, social media enables immediate feedback for all relevant parties (Mangold \& Faulds, 2009), which enables marketers to make strategic changes to address this feedback (Obal et al., 2011). Social media, thus, provides a very good platform for all businesses (big or small) to network and reach out to their target audience, connect with them directly and generate trust by listening to what they have to say (Taprial \& Kanwar, 2012), thereby facilitating marketing activities in an online social space of consumers, termed social media marketing. Social media marketing in consequence uses content generation, communication, outreach and referral to promote products and services via online social channels and platforms to increase web traffic, awareness and popularity of brands in online communities.

\subsection{Facebook, Social Media Marketing and Brand Equity}

Facebook is one of the most popular social-networking platforms and, as a social media tool, has been used to enhance brand and image communication. Facebook has proved to be a very useful and successful marketing tool as long as the strategy is well executed and the goals are realistic. The purpose of Facebook is to provide a platform where users interact with other users and online communities. In order to join the social network, users need to create a profile where they can present information about who they are, what they like, where they work, etc. Every profile has a "wall" where friends and followers can post comments and other information. The features for a company page are a little different from a personal page. Page administrators have the ability to create different tabs and write a short introduction about the company and furthermore provide contact information. This presents several opportunities for brands/companies to interact with consumers or followers. Within the aforementioned parameters, the ongoing Facebook experience offers a media tool for consumers to interact and write reviews about content in real time.

In 2008, Facebook released the 'page' feature for organizations, groups, and businesses to communicate with users and followers. This feature allows organizations and businesses to customize their Facebook presence and to interact with their followers in unique ways through status updates, upload of pictures, videos, links, and notes as well as the like feature (Facebook, 2009). Users on the page may interact with the content directly through comments or the like button and even upload content directly to the page's wall. These types of interactions allow businesses to establish authentic relationships with target consumers' markets whilst enhancing and reinforcing a strong brand presence online. Facebook provides a page's statistics to measure user interaction with the page and enable administrators to investigate not only how users are interacting with content in real time, but also the demographic characteristics of the most frequent users. 
As such, Facebook provides an opportunity for social media marketing by connecting brands and consumers through personalized channels (Facebook Pages) that facilitate user centred networking and social interaction with consumers in an online environment (Chi, 2011; Williams, 2009). This marketing is characterised by online brand communities (Taprial \& Kanwar, 2012); social interaction (Berselli, Burger \& Close, 2012; Fischer \& Reuber, 2011); content sharing (Babac, 2011); and accessibility (Taprial \& Kanwar, 2012). Business-to-consumer (B2C) marketers were quick to realize the value of social media, particularly Facebook, as a branding and marketing opportunity. Singh (2010) reports that Facebook has enabled consumer-facing businesses to interact with their customers in an entirely new way to increase brand awareness; build a brand community; nurture brand champions and express brand leadership. From the foregoing, the paper posits that:

H1: Facebook social media marketing relates positively to brand equity dimensions

H2: Like, Picture and Video interactions on Facebook pages relate positively to brand equity dimensions

\subsection{Methods and Data}

The study sought to investigate the degree to which social media marketing activities of MTN and Vodafone Ghana enhance their brand equity using Facebook as the social media channel. The MTN Group was launched in 1994 and is currently a leading mobile telecommunications company connecting subscribers in 22 countries in Africa, Asia and the Middle East. The MTN brand is most valuable in Africa, and ranked in the top 100 brands worldwide (MTN, 2015). MTN has a very active Facebook page with over 500,000 likes or followers. The posts on the MTN Facebook page focuses on providing user guides, products and services information, promotions and general company details. Vodafone Ghana, on the other hand, is an operating company of the Vodafone Group Plc., the world's leading mobile telecommunications company, with a significant presence in Europe, the Middle East, Africa, Asia Pacific and the United States (Vodafone, 2015). Vodafone Ghana currently has over 400,000 Facebook likes or followers. The Facebook page is an active page with posts on their promotions, packages, and general company information. Customers use the page as an avenue to report problems and to ask questions pertaining to the network. The Facebook pages for both MTN and Vodafone are verified, a confirmation of the validity and authenticity of the pages by Facebook.

The study used self-administered questionnaires to collect data in a cross-sectional survey within a 4-week period from subscribers who are followers of MTN and Vodafone Facebook pages in the Greater Accra Metropolis. The questionnaire items collected information pertaining to social media marketing activities of MTN and Vodafone on Facebook, and the impacts on brand equity and personal information of respondents. Social media marketing was measured as a second-order construct comprising of the three most frequently used Facebook interaction activities: like, picture interaction and video interaction. The Like tool provides an indication of a user's interest in news and content provided on the brand's page. Picture interaction enables users to communicate through pictures by commenting on a picture post on the page or uploading their own picture posts onto the page; and Video interaction enables users to communicate with videos through comments on a video post on the page or uploading their own video posts onto the page. Four dimensions of brand equity were measured: brand loyalty, perceived quality, brand association and brand awareness (Jensen, 2014; Aaker, 1996). Respondents were asked to indicate the extent to which social media marketing influences: (1) their decision to stay loyal to a specific brand (Brand Loyalty); (2) their perception of the brand's service quality and market leadership (Perceived Quality); (3) the perceived value of the brand's products and services (Brand Association); and (4) how they remember brands (Brand Awareness). All constructs were measured on multi-scale items and respondents were asked to indicate the extent to which they agree or disagree to statements on a 7-point Likert scale from strongly disagree to strongly agree. Overall, a total of 203 responses collected from subscribers of MTN and Vodafone were analysed.

\subsection{Analysis and Results}

The structural equations modelling (SEM) approach with SmartPLS 3.2 (Ringle, Will \& Wende, 2005) was used to analyze the proposed model. The PLS approach has the ability to maximize explained variance (Hair et al., 2009); hence, it is suitable for investigating the impacts of social media marketing on 
brand equity in Ghana's telecommunications sector. The data was subjected to a two-step analysis process: the measurement model validation; and the structural model estimation.

\subsection{Measurement Model Validation}

All concepts were modelled as reflective constructs for which reliability and convergent validity were assessed with Composite Reliability (CR) and Average Variance Extracted (AVE). Consistent with recommendations made by Chin (1998), results depicted in Table 1 below indicate acceptable reliability and validity of the measurement model with CR $>0.70$ and AVE $>0.50$. Discriminant validity was likewise confirmed in two ways in line with Chin's (1998) recommendations. To confirm discriminant validity, items showed high cross-loadings and the square root of the AVE shows that each factor shares a higher variance with items in its own construct than with items in other constructs (see Table 2 and Table 3).

Table 1: Reliability and Validity of Constructs

\begin{tabular}{llcl}
\hline & $\begin{array}{c}\text { Average } \\
\text { Extracted }\end{array}$ & $\begin{array}{c}\text { Variance } \\
\text { Reliability }\end{array}$ & $\begin{array}{l}\text { Composite } \\
\text { Alpha }\end{array}$ \\
\hline LIKE Brand Page & 0.588 & 0.876 & 0.823 \\
Picture Interaction & 0.665 & 0.908 & 0.874 \\
Video Interaction & 0.564 & 0.865 & 0.806 \\
Brand Loyalty & 0.523 & 0.841 & 0.764 \\
Brand Association & 0.616 & 0.889 & 0.844 \\
Brand Awareness & 0.580 & 0.873 & 0.819 \\
Perceived Quality & 0.504 & 0.834 & 0.752 \\
\hline
\end{tabular}

Table 2: Discriminant Validity of Constructs

\begin{tabular}{llllllll}
\hline & LIKE & PICT & VID & $\begin{array}{l}\text { Brand } \\
\text { Loyalty }\end{array}$ & $\begin{array}{l}\text { Brand } \\
\text { Assoc. }\end{array}$ & $\begin{array}{l}\text { Brand } \\
\text { Aware. }\end{array}$ & Quality \\
\hline LIKE Brand Page & 1 & & & & & & \\
Picture Interaction & & 1 & & & & & \\
Video Interaction & 0.562 & 0.515 & 1 & & & & \\
Brand Loyalty & 0.477 & 0.542 & 0.525 & 1 & & & \\
Brand Association & 0.547 & 0.549 & 0.562 & 0.624 & 1 & & \\
Brand Awareness & 0.495 & 0.491 & 0.515 & 0.626 & 0.576 & 1 & \\
Perceived Quality & 0.474 & 0.559 & 0.568 & 0.659 & 0.579 & 0.495 & 1 \\
Social Media Marketing & 0.779 & 0.838 & 0.849 & 0.658 & 0.684 & 0.598 & 0.681 \\
\hline
\end{tabular}

Table 3: Cross Loadings of Reflective Constructs

\begin{tabular}{cllllllll}
\hline & Association & Awareness & LIKE & Loyalty & PICT & $\begin{array}{l}\text { Perceived } \\
\text { Quality }\end{array}$ & $\begin{array}{l}\text { Social } \\
\text { Marketing }\end{array}$ & $\begin{array}{c}\text { Media } \\
\text { VID }\end{array}$ \\
\hline ba1 & 0.4847 & 0.7319 & 0.3451 & 0.3421 & 0.2910 & 0.3843 & 0.3702 & 0.3565 \\
ba2 & 0.4966 & 0.7382 & 0.3960 & 0.5689 & 0.4044 & 0.4784 & 0.4990 & 0.3969 \\
ba3 & 0.4864 & 0.8431 & 0.3958 & 0.5414 & 0.4061 & 0.4794 & 0.5052 & 0.4300 \\
ba4 & 0.3905 & 0.7469 & 0.3564 & 0.4362 & 0.3613 & 0.4153 & 0.4290 & 0.3890 \\
ba5 & 0.3332 & 0.7430 & 0.3853 & 0.4561 & 0.3902 & 0.5408 & 0.4510 & 0.3797 \\
bass1 & 0.8179 & 0.5289 & 0.4527 & 0.4706 & 0.4526 & 0.4963 & 0.6027 & 0.5111 \\
bass2 & 0.7644 & 0.4535 & 0.3985 & 0.4765 & 0.3195 & 0.4358 & 0.4076 & 0.3038 \\
\hline \multicolumn{2}{c}{ www.jbrmr.com } & A Journal of the Academy of Business and Retail Management (ABRM) & 117
\end{tabular}


Journal of Business and Retail Management Research (JBRMR), Vol. 13 Issue 3

\begin{tabular}{|c|c|c|c|c|c|c|c|c|}
\hline bass3 & 0.8106 & 0.4820 & 0.5166 & 0.4521 & 0.4735 & 0.4716 & 0.5929 & 0.5385 \\
\hline bass4 & 0.7906 & 0.3207 & 0.3331 & 0.5801 & 0.3622 & 0.4588 & 0.4746 & 0.3809 \\
\hline bass5 & 0.7364 & 0.4500 & 0.4164 & 0.4852 & 0.5037 & 0.4021 & 0.5570 & 0.4160 \\
\hline bl1 & 0.4478 & 0.5789 & 0.3662 & 0.7487 & 0.3719 & 0.4662 & 0.5117 & 0.4439 \\
\hline bl2 & 0.4962 & 0.4053 & 0.3200 & 0.7636 & 0.3852 & 0.4828 & 0.4684 & 0.3837 \\
\hline bl3 & 0.5588 & 0.5954 & 0.3840 & 0.8237 & 0.5556 & 0.6082 & 0.5688 & 0.3946 \\
\hline bl4 & 0.4628 & 0.4112 & 0.4299 & 0.7720 & 0.3890 & 0.5072 & 0.5154 & 0.4363 \\
\hline bl5 & 0.2114 & 0.1468 & 0.1661 & 0.4438 & 0.1686 & 0.2343 & 0.2356 & 0.1824 \\
\hline bpq1 & 0.3021 & 0.4441 & 0.2838 & 0.4572 & 0.4163 & 0.6623 & 0.5204 & 0.5086 \\
\hline bpq2 & 0.3238 & 0.5428 & 0.2705 & 0.4852 & 0.3452 & 0.5937 & 0.4034 & 0.3537 \\
\hline bpq3 & 0.4650 & 0.3526 & 0.3052 & 0.4332 & 0.3683 & 0.7560 & 0.4520 & 0.3270 \\
\hline bpq4 & 0.2843 & 0.3555 & 0.2299 & 0.4283 & 0.3864 & 0.7919 & 0.3992 & 0.3249 \\
\hline bpq5 & 0.6064 & 0.4480 & 0.5227 & 0.5099 & 0.4368 & 0.7287 & 0.5801 & 0.4484 \\
\hline like1 & 0.4476 & 0.4019 & 0.8601 & 0.3609 & 0.4622 & 0.3693 & 0.6337 & 0.4986 \\
\hline like1 & 0.4476 & 0.4019 & 0.8601 & 0.3609 & 0.4622 & 0.3693 & 0.6337 & 0.4986 \\
\hline like2 & 0.4277 & 0.3521 & 0.8359 & 0.3877 & 0.4176 & 0.3315 & 0.6044 & 0.4983 \\
\hline like2 & 0.4277 & 0.3521 & 0.8359 & 0.3877 & 0.4176 & 0.3315 & 0.6044 & 0.4983 \\
\hline like3 & 0.5697 & 0.4438 & 0.7836 & 0.4666 & 0.4127 & 0.4790 & 0.7162 & 0.5255 \\
\hline like3 & 0.5697 & 0.4438 & 0.7836 & 0.4666 & 0.4127 & 0.4790 & 0.7162 & 0.5255 \\
\hline like4 & 0.3437 & 0.3789 & 0.7112 & 0.3131 & 0.4295 & 0.3197 & 0.5378 & 0.3820 \\
\hline like4 & 0.3437 & 0.3789 & 0.7112 & 0.3131 & 0.4295 & 0.3197 & 0.5378 & 0.3820 \\
\hline like5 & 0.2366 & 0.3019 & 0.6182 & 0.2623 & 0.3623 & 0.2855 & 0.4477 & 0.3604 \\
\hline like5 & 0.2366 & 0.3019 & 0.6182 & 0.2623 & 0.3623 & 0.2855 & 0.4477 & 0.3604 \\
\hline pic1 & 0.4495 & 0.3466 & 0.4611 & 0.3814 & 0.7605 & 0.4446 & 0.6553 & 0.5121 \\
\hline pic1 & 0.4495 & 0.3466 & 0.4611 & 0.3814 & 0.7605 & 0.4446 & 0.6553 & 0.5121 \\
\hline pic2 & 0.3622 & 0.3608 & 0.4322 & 0.4950 & 0.8531 & 0.4704 & 0.6708 & 0.4368 \\
\hline pic2 & 0.3622 & 0.3608 & 0.4322 & 0.4950 & 0.8531 & 0.4704 & 0.6708 & 0.4368 \\
\hline pic3 & 0.5037 & 0.4204 & 0.4486 & 0.4346 & 0.8257 & 0.4568 & 0.7023 & 0.4563 \\
\hline pic3 & 0.5037 & 0.4204 & 0.4486 & 0.4346 & 0.8257 & 0.4568 & 0.7023 & 0.4563 \\
\hline pic4 & 0.3843 & 0.3806 & 0.4028 & 0.3441 & 0.7935 & 0.3727 & 0.5995 & 0.3965 \\
\hline pic4 & 0.3843 & 0.3806 & 0.4028 & 0.3441 & 0.7935 & 0.3727 & 0.5995 & 0.3965 \\
\hline pic5 & 0.5200 & 0.4811 & 0.4660 & 0.5306 & 0.8408 & 0.5172 & 0.7706 & 0.5016 \\
\hline pic5 & 0.5200 & 0.4811 & 0.4660 & 0.5306 & 0.8408 & 0.5172 & 0.7706 & 0.5016 \\
\hline vid1 & 0.5064 & 0.4592 & 0.5517 & 0.4860 & 0.5168 & 0.5477 & 0.7677 & 0.8318 \\
\hline vid1 & 0.5064 & 0.4592 & 0.5517 & 0.4860 & 0.5168 & 0.5477 & 0.7677 & 0.8318 \\
\hline vid2 & 0.4811 & 0.3668 & 0.4744 & 0.5116 & 0.4203 & 0.4992 & 0.6897 & 0.7025 \\
\hline vid2 & 0.4811 & 0.3668 & 0.4744 & 0.5116 & 0.4203 & 0.4992 & 0.6897 & 0.7025 \\
\hline vid3 & 0.3152 & 0.3098 & 0.4207 & 0.2569 & 0.3066 & 0.3138 & 0.5056 & 0.7346 \\
\hline vid3 & 0.3152 & 0.3098 & 0.4207 & 0.2569 & 0.3066 & 0.3138 & 0.5056 & 0.7346 \\
\hline vid4 & 0.4153 & 0.4017 & 0.4107 & 0.3508 & 0.4835 & 0.4596 & 0.6502 & 0.7984 \\
\hline vid4 & 0.4153 & 0.4017 & 0.4107 & 0.3508 & 0.4835 & 0.4596 & 0.6502 & 0.7984 \\
\hline vid5 & 0.3435 & 0.3724 & 0.3568 & 0.3030 & 0.3552 & 0.2274 & 0.5079 & 0.6753 \\
\hline vid5 & 0.3435 & 0.3724 & 0.3568 & 0.3030 & 0.3552 & 0.2274 & 0.5079 & 0.6753 \\
\hline
\end{tabular}




\subsection{Structural Model Estimation}

To assess the significance of the hypothesized paths in the research model, the bootstrapping procedure in SmartPLS was run (Hair et al., 2013). Results for the PLS algorithm showing standardized path coefficients $(\beta)$ and explanatory powers (R2) are shown in Figures 1 and 2 below.

\subsubsection{Does Facebook SMM generate brand equity in Ghana's Telecom sector?}

First, results (see Figure 1) show that social media marketing (modelled as a second order construct) positively impacts all dimensions of brand equity. This provides support for H1, which posits that Facebook social media marketing relates positively to brand equity dimensions. In other words, social media marketing activities on Facebook pages by MTN and Vodafone relate positively to brand awareness $(\beta=0.598, p$ value $=0.0000, p \leq 0.01)$; brand association $(\beta=0.684$, $p$ value $=0.0000, p \leq 0.01)$; brand loyalty $(\beta=0.658, \mathrm{p}$ value $=0.0000, \mathrm{p} \leq 0.01)$; and perceived quality $(\beta=0.681, \mathrm{p}$ value $=0.0000, \mathrm{p} \leq 0.01)$. The results further reveal that social media marketing through the Facebook Page feature is the reason for $46.80 \%$ of brand association, $46.4 \%$ of perceived quality, $43.3 \%$ of brand loyalty and $35.7 \%$ of brand awareness in Ghana's telecommunications sector.

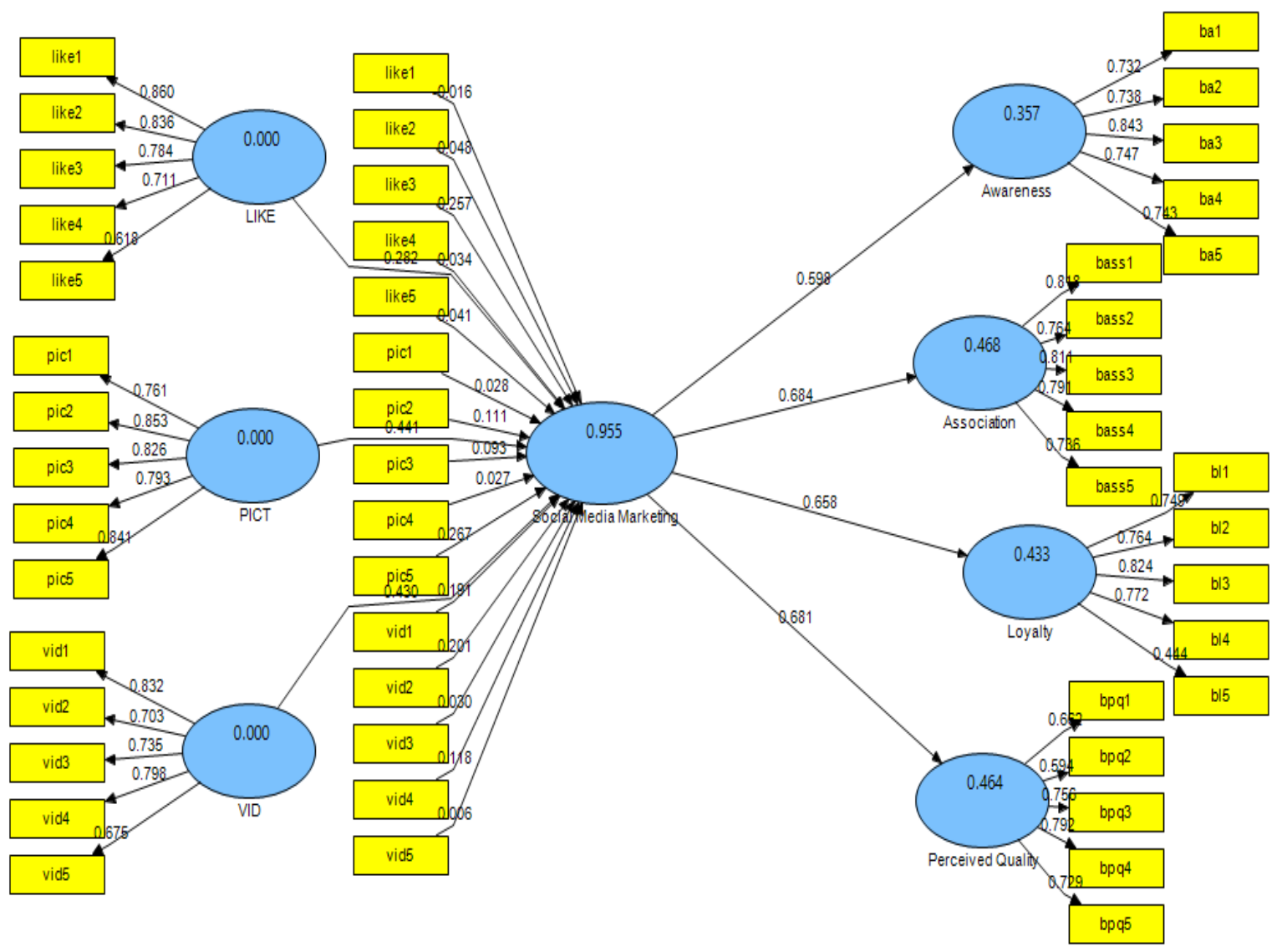

Figure 1: Overall Impacts of Social Media Marketing on Brand Equity 


\subsubsection{Which Facebook SMM activities generate brand equity in Ghana's telecom sector?}

The findings (see Figure 2) suggest that, overall, the three Facebook interaction activities assessed in the study all contribute to attaining brand equity at MTN and Vodafone. Picture interaction proved a significant contributor to brand equity: brand awareness $(\beta=0.228$, t stat $=2.021, p \leq 0.05)$; brand association $(\beta=0.283$, t stat $=2.312, \mathrm{p} \leq 0.05)$; brand loyalty $(\beta=0.314$, t stat $=3.102, \mathrm{p} \leq 0.01)$; and perceived quality $(\beta=0.315$, t stat $=2.884, p \leq 0.01)$. Liking a brand's page was found to significantly contribute to brand awareness $(\beta=0.220$, t stat $=2.011, p \leq 0.05)$, and brand association $(\beta=0.260, \mathrm{t}$ stat $=2.537, \mathrm{p} \leq 0.05)$ but not perceived quality $(\beta=0.102$, t stat $=1.008$, n.s. $)$, nor brand loyalty $(\beta=0.444$, t stat $=1.517$, n.s. $)$. Video interaction with consumers on Facebook was similarly found to significantly contribute positively to three dimensions of brand equity: brand loyalty $(\beta=0.259$, t stat $=2.021, p \leq 0.05)$; perceived quality $(\beta=0.334, \mathrm{t}$ stat $=2.884, \mathrm{p} \leq 0.05)$; and brand association $(\beta=0.266$, t stat $=1.991, \mathrm{p} \leq 0.05)$; but not brand awareness $(\beta=0.252$, $\mathrm{t}$ stat $=1.817$, n.s. $)$.

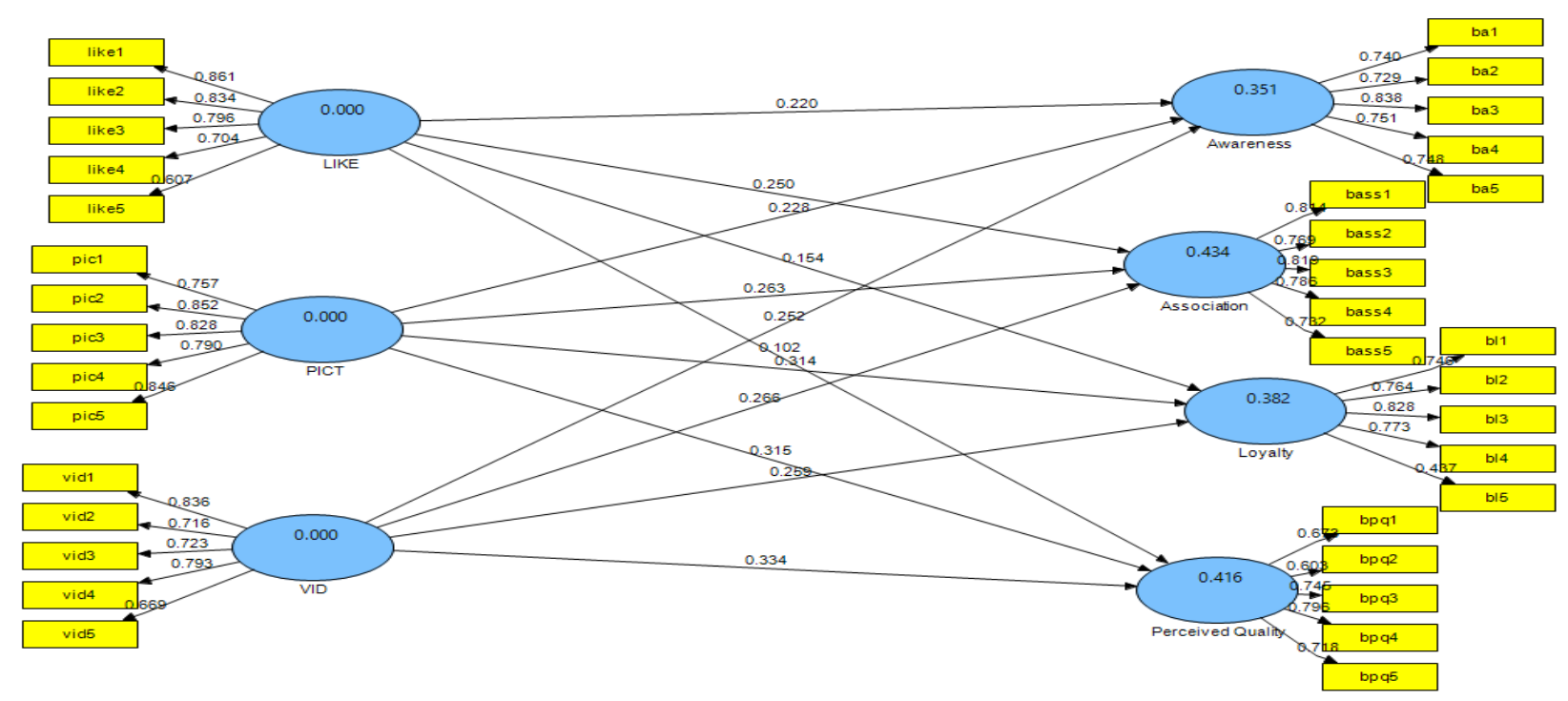

Figure 2: Impacts of Components of Social Media Marketing on Brand Equity

\subsection{Discussions}

The paper assessed the impact of social media marketing activities on brand equity focusing on subscribers of MTN and Vodafone in an empirical study. Facebook was chosen as the social media channel to test the premise of the study. In the process, relevant theoretical literature reviewed showed that social media marketing, when done properly, can lead to more customers, increased online traffic, and more conversions that, in turn, improves brand equity (Kim \& Ko, 2012; Ha, 2015). The findings reveal a positive significant relationship between social media marketing through Facebook Pages and the dimensions of brand equity in Ghana's telecom sector. Results further showed that social media marketing contributed more to the brand association, loyalty and perceived quality dimensions of brand equity.

Individually, the Facebook interaction activities assessed in the study proved relevant in attaining brand equity at MTN and Vodafone Ghana. In essence, whilst picture interaction with consumers generated significant improvements in all dimensions of brand equity, liking a brand's page is only a significant contributor to brand awareness and association, while video interaction also contributed significantly only to brand loyalty and perceived quality. This indicates that social media marketing activities should not be pursued in isolation but should be approached holistically to obtain optimum benefits. In summary, the research results suggest that MTN and Vodafone actively engage customers through social media marketing activities on Facebook - brand page liking, picture and video interactions, and these have yielded significantly positive impacts on their brand equity. This implies that managers should invest in social media marketing activities that customers are likely to respond to, and this should guide their strategy development efforts. 


\subsection{Conclusions}

Social media has evolved to become a formidable and useful tool in marketing and brand communication. Consequently, social media marketing is greatly helping companies and consumers find new communication routes. Brands expand their communication with customers and increase customer loyalty day by day. As an integrated marketing medium, social media marketing activities effectively enhance brand equity by providing novel value to customers that traditional marketing media do not usually provide. The findings affirm these characteristics of social media marketing and prove that network service operators in Ghana's telecom sector who actively engage their customers on social media gain from the social media marketing activities.

\subsection{Research Limitations}

The study has a few limitations, which can be explored further by future studies. The population comprised of students and workers within the Greater Accra Region who own and belong to at least one social media channel - preferably, Facebook. Future studies could consider the other regions of Ghana. Likewise, the study focused on subscribers of MTN and Vodafone, so again future studies can expand to look at other telecoms in Ghana.

\section{References}

Aaker, D. A. (1991). Managing Brand Equity. NY: The Free Press

Aaker, D. A. (1996). Measuring Brand Equity Products and Markets. California Management Review, 38 (3).

Ateş B. H. (2013). A study on the effects of social media on young consumers' buying behaviours. European Journal of Research on Education, 65-74.

Babac, R. (2011). Impact of Social Media Use on Brand Equity of Magazine Brands. Sweden: Halmstad University.

Berselli, S., Burger, S. and Close, J. (2012). Crisis Mapping Community Social Media Information During and After LargeScale Disasters in Victoria. Victoria: Worcester Polytechnic Institute

Campbell, C. L., Leyland, F. P., Michael, M. P. and Pierre, R. B. (2011). Understanding Consumer Conversations around Ads in a Web 2.0 World. Journal of Advertising, 40(1), 87-102.

Chi, H.H (2011). Interactive Digital Advertising VS. Virtual Brand Community: Exploratory Study of User Motivation and Social Media Marketing Responses in Taiwan. Journal of Interactive Advertising, 12, 44-61.

Christodoulides, G., Chernatony, L., Furrer, O., Shiu, E. and Abimbola, T. (2006). Conceptualizing and Measuring the Equity of Online Brands. Journal of Marketing Management, 22 (7-8), 799-825.

Cox, S. A. (2010). Online Social Network Member Attitude Toward Online Advertising Formats. MA thesis, The Rochester Institute of Technology.

Dryer, R. L. (2010). Advising Your Clients (and You!) in the New World of Social Media: What Every Lawyer Should Know About Twitter, Facebook, Youtube \& Wikis. Utah Bar Journal, 3(23), 16-21.

Duan, W., Gu, B. and Whinston, A. B. (2008). Do Online Reviews Matter? An empirical investigation of panel data. Decision Support Systems, 45(4), 1007-1016.

Erdogmus,I.E and Cicek, M (2012). The Impact of Social Media Marketing on Brand Loyalty. Social and Behavioral Sciences, 58, 1353-1360. DOI: 10.1016/j.sbspro.2012.09.1119.

Facebook Pages Product Guide. (2009). Retrieved October 1 2015, from http://www.boulderdowntown.com/_files/docs/facebookpagesproductguide.pdf

Faraj, S., Jarvenpaa, S. L. and Majchrzak, A. (2011). Knowledge collaboration in online communities. Organization Science, 22(5), 1224-1239.

Fischer, E. and Reuber, R. (2011). Social interaction via new social media: (How) can interactions on Twitter affect effectual thinking and behaviour? Journal of Business Venturing, 26, 3-21.

Gensler, S., Valckner, F., Liu-Thompkins, Y. \& Wiertz, C. (2013). Managing Brands in the Social Media Environment. Journal of Interactive Marketing, 27, 242-256. DOI: 10.1016/j.intmar.2013.09.004.

Godes, D. and Mayzlin, D. (2004). Using online conversations to study word-of-mouth communication. Marketing Science, 23(4), 545-60.

Gordhamer, S. (2009). 4 ways social media is changing business. Retrieved May 25, 2015 from http://mashable.com/2009/09/22/ social-media-business/

Ha, A. (2015). Facebook Says There Are Now 40M Active Small Business Pages. Retrieved October 12, 2015, from http://techcrunch.com/2015/04/29/facebook-40-million/\#.xzzebe:ff9d

Hair, J. F., Anderson, R. E., Tatham, R. L. and Black, W.C. (2009). Multivariate Data Analysis, Fifth Edition, PrenticeHall: Upper Saddle River.

Issaka, S. (2015). The Rise of Social Media in Ghana. Retrieved July 16, 2015 from

http://www.tabj.co.za/western_africa/blogging_ghana_is_more_than_just_a_platform_for_bloggers_to_netw.html

www.jbrmr.com A Journal of the Academy of Business and Retail Management (ABRM) 
Jensen, T. (2014). Facebook brand equity: A study of how to utilize social media to improve brand equity. Copenhagen Business School.

Joshi, K. D., Chi, L., Datta, A. and Han, S. (2010). Changing the Competitive Landscape: Continuous Innovation through IT Based Knowledge Capabilities. Information Systems Research, 21(3), 472-495.

Kaplan, A. M. and Haenlein,M. (2010). Users of the World, Unite! The Challenges and Opportunities of Social Media. Business Horizons, 53, 59-68.

Keller, K. L. (2009) Building strong brands in a modern marketing communications environment, Journal of Marketing Communications, 15(2-3), 139-155, DOI: 10.1080/13527260902757530

Kim A. J. and Ko, E. (2012). Do social media marketing activities enhance customer equity? An empirical study of luxury fashion brand. Journal of Business Research, 65, 1480-1486.

Kim, K. H., Kim, K. S., Kim, D. Y., Kim, J. H. and Kang, S. H. (2008). Brand equity in hospital marketing". Journal of Business Research, 61(1), 75-82.

Laduque, J. (2010). Franchising World: “Get More Leads, Engage Customers with Social Media. Retrieved July 23, 2015 from http:/ / www.franchise.org/get-more-leads-engage-customers-with-social-media

Majchrzak, A., Cooper, L. P. and Neece, O. E. (2004). Knowledge Reuse for Innovation. Management Science, 50(2), 174188.

Mangold, W. G. and Faulds, D. J. (2009). Social media: The new hybrid element of the promotion mix. Business Horizons, 52, 357-365.

Mitchell, A., \& Holcomb, J. (2015). State of the news media 2015. Pew Research Center, 29.

Mashable (n.d). Social Media Marketing definition. Retrieved May 12, 2015, from http://mashable.com/category/socialmedia-marketing/

Morrissey, B. (2007). Social media sites replacing microsites in marketing mix. Brandweek, 48 (41), 5.

MTN Ghana Facebook page (2015). Retrieved October 212015, from https:/ / www.facebook.com/MTNGH

Neti, S. (2011). Social media and its role in marketing. International Journal of Enterprise Computing and Business Systems, 1(2), 1-15

Nielsen (2009). Nielsen Global Online Consumer Survey: Trust, Value and Engagement in Advertising. Retrieved July 16, 2015 from http://www.nielsen.com/content/dam/corporate/us/en/newswire/uploads/2009/07/ trustinadvertising0709.pdf

Obal, M., Burtch, G., and Kunz, W. (2011). How can social networking sites help us? The role of online weak ties in the IMC mix. International Journal of Integrated Marketing Communications, 3(2), 33-47.

Pitta, D. A. \& Katsanis, L. P. (1995). Understanding brand equity for successful brand extension. Journal of Consumer Marketing, 12(4), 51-64, DOI: 10.1108/07363769510095306

Rangaswamy, A., Burke, R. R. and Oliva, T. A. (1993). Brand equity and the extendibility of brand names. International Journal of Research in Marketing, 10(1), 61-75.

Reynolds, T. J. and Phillips, C. B. (2005). In search of true brand equity metrics: all market share ain't created equally. Journal of Advertising Research, 45(2), 171- 186.

Richter, A. \& Koch, M. (2007). Social software-status quo und Zukunft. München: Fakultät für Informatik, Universität der Bundeswehr München. Available at http://www.unibw.de/wow5_3/forschung/social_software.

Ringle, C. M., Wende, S., \& Will, A. (2005). SmartPLS 2.0 M3. Hamburg: University of Hamburg

Rowley, J. (2009). Online branding strategies of UK fashion retailers. Internet Research, 19(3), 348 - 369.

Singh, S. (2010). Social Media Marketing for Dummies. Indianapolis: Wiley Publishing, Inc.

Taprial, V. and Kanwar, P. (2012). Understanding Social Media. United States: Ventus Publishing.

Vodafone Ghana Facebook page (2015). Retrieved October 212015, from

Williams, R. (2009). What is social media marketing. Retrieved February, 10, 2013.

Wolny, J. \& Mueller, C. (2013). Analysis of fashion consumers' motives to engage in electronic word-of-mouth communication through social media platforms. Journal of Marketing Management, 29(5), DOI: 10.1080/0267257X.2013.778324.

Yazdanparast, A., Joseph, M., \& Qureshi, A. (2015). An investigation of Facebook boredom phenomenon among college students. Young Consumers, 16(4), 468-480, https:/ / doi.org/10.1108/YC-02-2015-00506

Yoo, B. \& Donthu, N. (2001). Developing and Validating a Multidimensional Consumer-Based Brand Equity Scale. Journal of Business Research, 52, 1-14. DOI: 10.1016/S0148-2963(99)00098-3. 